\title{
ENTREPRENEURIAL ECOSYSTEM IN THE REPUBLIC OF MOLDOVA: THE ROLE OF GOVERNMENT POLICY
}

\author{
Ana CIRLAN ${ }^{1}$, PhD Student, \\ Academy of Economic Studies of Moldova
}

\author{
DOI: https://doi.org/10.36004/nier.es.2021.1-06 \\ JEL Classification: F2, F68, K2, L26, L38, M2, 020, 029, 044 \\ UDC: 338.22:334.722(478)
}

\section{ABSTRACT}

The article presents and analyses the entrepreneurial ecosystem in the Republic of Moldova, as a solution for an integrated approach to the problems of entrepreneurs. Entrepreneurial ecosystems represent a set of interdependent actors and coordinated factors so as to increase the productivity of SMEs. The paper includes: (I) investigating the literature on entrepreneurial ecosystems; (II) analysis of the role of public policies in creating and supporting entrepreneurial ecosystems; (III) finalizing the components of the entrepreneurial ecosystem in the Republic of Moldova and performing their evaluation through the prism of international rankings. The aim of this research is to elucidate the role of entrepreneurial policies with a holistic approach to the creation of the entrepreneurial ecosystem. The key challenge for the authorities is to identify the pillars that contribute to the development of an ecosystem. However, the existence of a large number of entrepreneurial support programs and projects does not necessarily lead to a qualitative increase in the number of enterprises. The results of the research showed that the authorities promote policies to support the business environment with a fragmented approach and an emphasis on increasing quantitative indicators. At the same time, the analysis of the components of the entrepreneurial ecosystem in the Republic of Moldova, through international rankings, indicates the deterioration of the business environment conditions. The research methodology is based on the analysis of policy documents on SME support and data provided by reports of international organizations (World Bank, World Economic Forum, Organization for Economic Cooperation and Development, etc.).

Keywords: entrepreneurial ecosystem, public policies, international ranking, analysis.

Articolul prezintă și analizează ecosistemul antreprenorial din Republica Moldova, drept soluție pentru o abordare integrată a problemelor antreprenorilor. Ecosistemele antreprenoriale reprezintă un set de actori interdependenți și factori coordonați astfel încât să sporească productivitatea întreprinderilor mici și mijlocii într-un anumit teritoriu. Lucrarea include: (I) investigarea literaturii de specialitate privind ecosistemele antreprenoriale; (II) analiza rolului politicilor publice în crearea și susținerea ecosistemelor antreprenoriale; (III) definitivarea componentelor ecosistemului antreprenorial din Republica Moldova și efectuarea evaluării acestora prin prisma clasamentelor internaționale. Scopul prezentei cercetări este de a elucida rolul politicilor antreprenoriale cu abordare holistică la crearea ecosistemului antreprenorial din Republica Moldova. Provocarea cheie pentru autorități care încearcă să abordeze politicile privind ecosistemele antreprenoriale rezidă în identificarea pârghiilor, pilonilor care contribuie la dezvoltarea unui ecosistem și direcționarea eforturilor întru crearea / consolidarea acestora. Or, existența unui număr mare de programe și proiecte de suport antreprenorial nu neapărat duc la creșterea calitativă a numărului de întreprinderi dintr-o zonă geografică. Rezultatele cercetării au arătat că autoritățile promovează politici de susținere a mediului de afaceri cu abordare fragmentară și accent pe creșterea indicatorilor cantitativi. Totodată, analiza componentelor ecosistemului antreprenorial din Republica Moldova, prin prisma clasamentelor internaționale, indică deteriorarea condițiilor mediului de afaceri și implicit existența unui șir de impedimente cu care se confruntă antreprenorii. Metodologia cercetării se bazează pe analiza documentelor de politici privind susținerea IMM-urilor și a datelor oferite de rapoartele organizațiilor internaționale (Banca Mondială, Forumul Economic Mondial, Organizația pentru Cooperare și Dezvoltare Economică, etc.), privind nivelul de dezvoltare economică a țării, mediului de afaceri, capitalului uman etc.

Cuvinte-cheie: ecosistem antreprenorial, politici publice, clasamente internaționale, analiză.

${ }^{1}$ ID ORCID 0000-0003-1751-9725 $\$ e-mail: anapavalachi@yahoo.com 
В статье представлена и проанализирована предпринимательская экосистема в Республике Молдова, как решение для комплексного подхода $\kappa$ проблемам предпринимателей. Предпринимательские экосистемы - совокупность взаимозависимых субъектов и координированных факторов, направленных на повышение производительности малых и средних предприятий на определенной территории. Работа включает: (I) исследование литературы по предпринимательским экосистемам; (II) анализ роли государственной политики в создании и поддержке предпринимательских экосистем; (III) доработка компонентов предпринимательской экосистемы 8 Республике Молдова и выполнение их оценки через призму международных рейтингов. Цель данного исследования - выяснить роль предпринимательской политики с целостным подходом к созданию предпринимательской экосистемы в Республике Молдова. Основная задача властей, пытающихся реализовать политику предпринимательской экосистемы, состоит в том, чтобы определить компоненты, которые способствуют развитию экосистемы, и направить усилия на их укрепление. Наличие большого количества программ и проектов поддержки предпринимательства не обязательно ведет к качественному увеличению количества предприятий в географическом районе. Результаты исследования показали, что власти продвигают политику поддержки деловой среды с фрагментарным подходом и акцентом на увеличение количественных показателей. В то же время, анализ компонентов предпринимательской экосистемы в Республике Молдова через призму международных рейтингов указывает на ухудшение условий деловой среды и косвенно на наличие ряда препятствий, с которыми сталкиваются предприниматели. Методология исследования основана на анализе программных документов по поддержке МСП и данных отчетов международныхорганизаций (Всемирного банка, Всемирного экономического форума, Организации экономического сотрудничества и развития и др.) об уровне экономического развития страны, окружающей среды. бизнес, человеческий капитал и др.

Ключевые слова: предпринимательская экосистема, государственная политика, международные рейтинги, анализ.

\section{INTRODUCTION}

There is a global recognition of the fact that the development of successful small and mediumsized enterprises is one of the main prerequisites for the prosperity of local economies. Creating a sustainable and competitive entrepreneurial ecosystem is at the heart of efforts to increase incomes and well-being in regional economies. Despite the relative novelty of the entrepreneurial ecosystem concept, it rapidly caught the attention of authorities, international organizations, business environment and academia. A distinguished feature of the entrepreneurial ecosystem is the environment in which the company/firm operates. However, the company's activity is directly and undoubtedly influenced by external environmental factors, such as: access to finance and knowledge, the market, authorities and the regulatory framework, support and consulting services, competitors, culture, etc. The entrepreneurial ecosystem can be described as a generic context aimed at promoting entrepreneurship in a region. Therefore, it consists of a horizontal network (customers and suppliers) and a vertical network (competitors and partners). It also includes organizations that support entrepreneurs: public or private financing agencies (banks, business angels, venture capital, etc.); support infrastructure (business incubators, consultants, etc.); research organizations (research centers, laboratories, etc.); and consortia of enterprises (active enterprises, associations and unions,

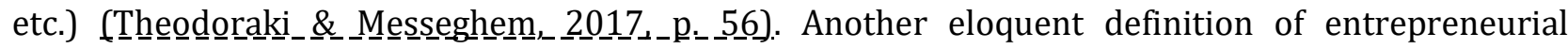
ecosystems, which also refers to the concept of sustainability, states that they are an interconnected group by actors from a certain geographical area, committed to sustainable development by providing

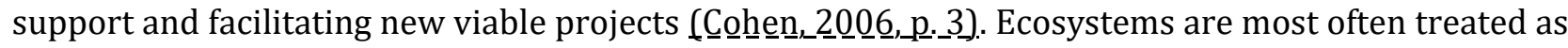
a set of interconnected entrepreneurial actors (both potential and existing), entrepreneurial organizations (firms, venture capitalists, business angels and banks), institutions (universities, public sector agencies and financial institutions) and entrepreneurial processes (for example, business growth rate, number of high-growth firms, etc.) that work together formally and informally to increase

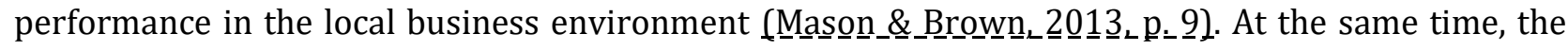
isolated existence of actors is not enough to ensure a functioning ecosystem, as Stam argues, entrepreneurial networks, leadership, finance services, talent, knowledge and support are at the heart 
of the ecosystem, but in addition to the presence of these elements, the interaction between them is important to determine the success of the ecosystem (Stam, 201 2015, p. 17666).

Although there is no unanimously accepted definition for the notion of entrepreneurial ecosystem, the literature studied allows us to point out the following common features of this concept:

$>$ A delineated geographical area;

$>$ A set of elements/actors of the ecosystem;

$>$ Interaction/collaboration between elements;

$>$ Development, performance, economic rise.

Research on entrepreneurial ecosystems has evolved and there is relevant previous work on clusters, industrial districts and innovation clusters. (Roundy, 2016) Most studies have focused on large urban areas, such as Silicon Valley, Boston, Washington DC, and Boulder Colorado (Feldmanan et

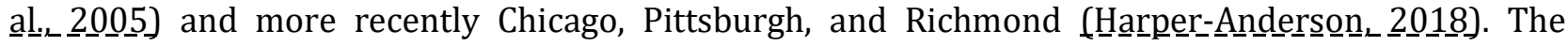
mentioned research focused on the attributes of entrepreneurial ecosystems, focusing on different components, how they interact and what aspects allow for the growth and development of ecosystems. Most studies that address the subject analyze the evolution and process by which an ecosystem was

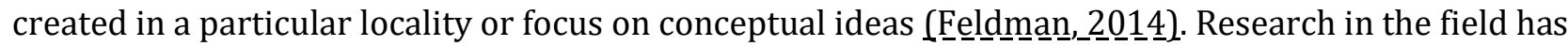
been criticized for focusing mainly on successful ecosystems in urban environments, but also for listing the attributes of the ecosystem without considering the causality and stages through which ecosystems

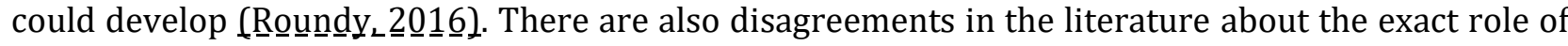
certain attributes, some for example - show that universities are extremely important, while others claim that they are less conclusive. The role of public policy in supporting and creating entrepreneurial ecosystems is also unclear (Feld, 2012). The concept of entrepreneurial ecosystem has captured the attention of the authorities largely due to the fact that it is associated with the increase in the number of jobs and companies with high development potential (Mason and Brown, 2014).

The key challenge for authorities trying to address entrepreneurial ecosystem policies is to identify the levers, pillars that contribute to the development of an ecosystem and direct efforts to create/strengthen them. At the same time, it should be pointed out that the existence of a large number of programs and projects to support entrepreneurship does not necessarily lead to a qualitative increase in the number of enterprises in a geographical area. Respectively, the emphasis should be on the conditions under which companies operate or on creating a business-friendly ecosystem. The aim of this paper is to critically examine the role of public policies with a holistic approach in the formation of entrepreneurial ecosystems in the Republic of Moldova.

\section{LITERATURE REVIEW}

\section{Synthesizing theoretical approaches to the entrepreneurial ecosystem and the role of government policy}

The process of creating and developing the entrepreneurial ecosystem is a relatively new one, which has, in a short time, gained the attention of governments, development agencies, researchers and academia. Organizations and institutions such as: the World Bank, the World Economic Forum, Babson College or the Organization for Economic Cooperation and Development, etc. approached the multilateral concept, presenting definitions, components and tools for assessing the entrepreneurial ecosystem.

The concept of the entrepreneurial ecosystem encompasses the interconnection of social, political, economic and cultural components, which contribute to the creation and growth of innovative companies with major development potential. As originally defined by Dubini, ecosystems (or as she calls them, environments) are characterized by the presence of family businesses and examples of success, diverse economies, strong business infrastructure, access to finance, entrepreneurial culture and public policies that stimulates the creation of added value (Dubini, 1989). What distinguishes the concept from other approaches to economic policies is that the entrepreneurial ecosystem assigns the central role in creating the system to the entrepreneur. The entrepreneur is the one who constantly faces impediments, seeks solutions, identifies opportunities, he is the one who best perceives the environment in which he operates and its shortcomings. This "privatization" of entrepreneurship policy diminishes the role of government compared to traditional policy approaches - thus, the role of the state remains just as important, except that its prerogative becomes the creation of conditions adapted to the needs of the ecosystem. (Feld, 2012) 
Along with the key role of entrepreneurs in ecosystem development, the latest research in the field offers key components, the interaction between elements, access to the necessary resources, but also the role of authorities in these systems. Feld offers nine attributes designed to create a thriving entrepreneurial ecosystem: leadership, infrastructure, support networks and services, partnership building events, government support, cooperation between large companies and SMEs with high growth potential, financial resources (Table 1).

Table 1

\section{Nine attributes of a successful start-up community}

\begin{tabular}{|c|c|}
\hline Attribute & Description \\
\hline Leadership & $\begin{array}{l}\text { Strong group of entrepreneurs who are visible, accessible and committed } \\
\text { to the region becoming a great place to start and grow a company. }\end{array}$ \\
\hline Intermediaries & $\begin{array}{l}\text { Many well-respected mentors and advisors giving back across all stages, } \\
\text { sectors, demographics and geographies as well as a solid presence of } \\
\text { effective, visible, well-integrated accelerators and incubators. }\end{array}$ \\
\hline Network density & $\begin{array}{l}\text { Deep, well-connected community of start-ups and entrepreneurs along } \\
\text { with engaged and visible investors, advisors, mentors and supporters. } \\
\text { Optimally, these people and organizations cut across sectors, } \\
\text { demographics and culture engagement. Everyone must be willing to give } \\
\text { back to their community. }\end{array}$ \\
\hline Government & $\begin{array}{l}\text { Strong government support for and understanding of start-ups to } \\
\text { economic growth. Additionally, supportive policies should be in place } \\
\text { covering economic development, tax and investment vehicles. }\end{array}$ \\
\hline Talent & $\begin{array}{l}\text { Broad, deep talent pool for all levels of employees in all sectors and areas } \\
\text { of expertise. Universities are an excellent resource for start-up talent and } \\
\text { should be well connected to community. }\end{array}$ \\
\hline $\begin{array}{l}\text { Support } \\
\text { services }\end{array}$ & $\begin{array}{l}\text { Professional services (legal, accounting, real estate, insurance and } \\
\text { consulting) are integrated, accessible, effective and appropriately priced. }\end{array}$ \\
\hline Engagement & $\begin{array}{l}\text { Large number of events for entrepreneurs and community to connect, with } \\
\text { highly visible and authentic participants (e.g. meet-ups, pitch days, start- } \\
\text { up weekends, boot camps, hackathons and competitions). }\end{array}$ \\
\hline Companies & $\begin{array}{l}\text { Large companies that are the anchor of a city should create specific } \\
\text { departments and programs to encourage cooperation with high-growth } \\
\text { start-ups. }\end{array}$ \\
\hline Capital & $\begin{array}{l}\text { Strong, dense and supportive community of venture capitalists, angels, } \\
\text { seed investors and other forms of financing should be available, visible and } \\
\text { accessible across sectors, demographics and geography. }\end{array}$ \\
\hline
\end{tabular}

Source: Feld (2012, pp. 186-187).

The entrepreneurial ecosystem is a complex mechanism, as described by Feld (Table 1), which includes the physical support infrastructure (clusters, business incubators, institutions, financiers, large companies, universities, etc.); support services (consulting, partnerships, access to finance, investors, meetings and communication, etc.); human resources (talents, successful entrepreneurs, experts, etc.). The element that defines a start-up community is the realization of the connection, interaction and a continuous connection between actors involved in the ecosystem. So, to have a functioning entrepreneurial ecosystem it is not enough to have talented people, institutions and support and consulting services, businesses and companies. It is imperative to ensure cooperation, to catalyze the process of connection between stakeholders, so the process includes the creation of the community, but also its growth.

Isenberg of Babson College has written a series of articles on the concept of the entrepreneurial ecosystem. He argues that there is no exact formula for creating the ecosystem, but the authorities must follow the following nine principles for creating it: 1 . Do not try to imitate the Silicon Valley model; 2 . Create the ecosystem considering the conditions of the local environment; 3 . Involve the business environment from the start; 4. Identify new ways of financing; 5 . Do not overload the clusters; facilitate the organic/natural development of ecosystems, accept ambitious projects; 6. Favor businesses with high development potential; 7. Involve entrepreneurs in decision-making within 
companies and institutions; 8 . Continuously address cultural change; 9 . Reform the legal, bureaucratic and regulatory framework (Is_enberg,_2010 0 ). At the same time, Isenberg proposes six distinct areas of the entrepreneurial ecosystem: politics, finance, culture, support, human capital and markets (Isenberg,_2011). These six areas are largely found in the paper prepared by the World Economic Forum (Table 2).

Table 2

Entrepreneurial ecosystem pillars and their components

\begin{tabular}{|l|l|}
\hline \multicolumn{1}{|c|}{ Pillar } & \multicolumn{1}{|c|}{ Components } \\
Accessible markets & $\begin{array}{l}\text { Domestic market: large/medium/small companies as customers and } \\
\text { governments as customer. } \\
\text { Foreign market: large/medium/small companies as customers and } \\
\text { governments as customer. }\end{array}$ \\
\hline Human capital/workforce & $\begin{array}{l}\text { Management talent, technical talent, entrepreneurial company experience, } \\
\text { outsourcing availability and access to immigrant workforce. }\end{array}$ \\
\hline Funding \& finance & $\begin{array}{l}\text { Friends and family, angel investors, private equity, venture capital and access } \\
\text { to debt. }\end{array}$ \\
\hline Support systems/mentors & $\begin{array}{l}\text { Mentors/advisors, professional services, incubators/accelerators and } \\
\text { networks of entrepreneurial peers. }\end{array}$ \\
\hline $\begin{array}{l}\text { Government \& regulatory } \\
\text { framework }\end{array}$ & $\begin{array}{l}\text { Ease of starting a business, tax incentives, business-friendly } \\
\text { legislation/policies, access to basic infrastructure, access to } \\
\text { telecommunications/broadband and access to transport. }\end{array}$ \\
\hline Education \& training & $\begin{array}{l}\text { Available workforce with pre-university education, available workforce with } \\
\text { university education and those with entrepreneurship-specific training. }\end{array}$ \\
\hline $\begin{array}{l}\text { Major universities as } \\
\text { catalysts }\end{array}$ & $\begin{array}{l}\text { Promoting a culture of respect for entrepreneurship, playing a key role in } \\
\text { idea-formation for new companies and playing a key role in providing } \\
\text { graduates to new companies. }\end{array}$ \\
\hline Cultural support & $\begin{array}{l}\text { Tolerance for risk and failure, preference for self-employment, success } \\
\text { stories/role models, research culture, positive image of entrepreneurship } \\
\text { and celebration of innovation. }\end{array}$ \\
\hline
\end{tabular}

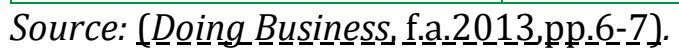

The pillars proposed by the World Economic Forum for a successful ecosystem focus on the presence of key factors (resources), such as human capital, finance and services; formal (government and regulatory framework) and informal (cultural support) institutions that allow entrepreneurs access to internal and external markets. The model of the entrepreneurial ecosystem proposed by the World Economic Forum emphasizes the creation of the entrepreneurial culture and the positive image of the businessman, the promotion of talents, of qualified human resources. In addition to access to finance, support from the authorities and the existence of accessible markets, there is a need to create a culture that promotes entrepreneurial values.

\section{DATA SOURCES AND USED METHODS}

The research methodology is based on the critical analysis of public policy documents on SME support and data provided by reports of international organizations (World Bank, World Economic Forum, Organization for Economic Co-operation and Development, etc.) on the country's level of economic development, its business environment, human capital, etc.

\section{THE RESULTS OF OWN RESEARCH AND DISCUSSIONS}

Traits of the existing legal framework, oriented on the development and support of the business environment in the Republic of Moldova.

Inspired by international research and international good practice, which confirms the importance of entrepreneurial development for sustainable economic growth, the authorities implement policies and programs to support the small and medium-sized enterprise (SME) sector. So far, these policies are mainly aimed at increasing the number of enterprises and quantitative indicators on their activity, being mainly aimed at providing support in the form of funding and 
training for narrowly selected segments of entrepreneurs, such as: emigrants, young people, women, etc. (Table 3) The main authority empowered to implement projects and programs on SME development is the Organization for the Development of the Small and Medium Enterprises Sector (ODIMM). ODIMM is a public, non-commercial, non-profit institution created by Government Decision no. 538 of May 17, 2007, which operates in coordination with the Ministry of Economy and with other central and local authorities, business associations, business support providers and SMEs.

Table 3

\begin{tabular}{|l|l|}
\multicolumn{2}{|c|}{ Projects aimed at the development of target groups of entrepreneurs } \\
\hline Target group & Project/program \\
\hline Emigrants & "PARE 1 + 1" Program for attracting remittances in the economy \\
\hline \multirow{3}{*}{ Youth } & "Start for Youth - a sustainable business at your home" National program \\
\cline { 2 - 2 } & "Joint Opportunities in Business for Youth" (JOBS4Youth) Project \\
\cline { 2 - 2 } & "Lead your way to business" Project \\
\cline { 2 - 2 } & National program for youth economic empowerment (PNAET) \\
\hline \multirow{2}{*}{ Women } & "Women in business" National pilot-program \\
\cline { 2 - 2 } & "Business Academy for Women" (BAW) Project \\
\hline
\end{tabular}

Source: Developed by author

The development and support of the business environment in the Republic of Moldova is a priority for the authorities, being stipulated in the National Development Strategy "Moldova 2020": 8 solutions for economic growth and poverty reduction; Strategy for the development of the small and medium enterprises sector for the years 2012-2020; National strategy for attracting investments and promoting exports for the years 2016-2020. These strategic documents address the evolution of the business environment from a quantitative and less qualitative perspective, thus the successful implementation of the Small and Medium Enterprise Sector Development Strategy for 2012-2020 (GD of the Republic of Moldova on the approval of the Small Business Development Strategy and mediumsized enterprises for the years 2012-2020 No. 685 of 13.09.2012), was to contribute to: increasing the number of SMEs to 25 per 1000 inhabitants, increasing the number of employees in the sector, increasing the sector's contribution to GDP and increasing the SME contribution in total exports. "Traditional" government entrepreneurial policies, as classified by Mason and Brown, address the development of a particular type of enterprise or a distinct geographical area (Mason_ $\underline{\&}$ Brown $\underline{n}$, 2013). Many of the initiatives and programs of the Government of the Republic of Moldova are addressed to rural businesses and economically disadvantaged areas. Business incubators were created, financing programs, training and support for the rural environment were developed. However, these initiatives have a low impact on regional economic development and do not help reduce regional disparities, the largest share, over $65 \%$ of businesses are created and operate in Chisinau, generating over $70 \%$ of sales revenues in the country and approx. 94\% of the income tax on entrepreneurial activity. Entrepreneurs do not create businesses because support and consulting services are available, rather these services are requested as a result of the existence and activity of entrepreneurs. Although these services are urgently needed, they are not enough to rapidly develop the economy of a region or

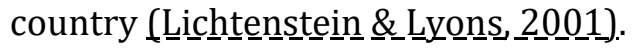

"Traditional" policies usually aim to increase the number of enterprises, but do not focus on the quality or potential of these companies (Figure 1).

A different set of policies is needed than those aimed at setting up businesses in general. Simply focusing policy efforts on increasing the number of new businesses has little effect, as very few companies subsequently have the potential to develop and create added value. The financial resources provided by the state through support programs are aimed at stimulating certain categories of entrepreneurs, such as: young people, women, exporters, etc.; or to the development of certain sectors: production, information technologies, agriculture, etc. This fragmented approach in developing support policies and programs only partially meets the needs of entrepreneurs. 


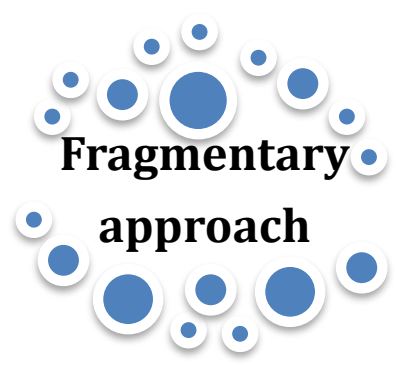

-support programmes and policies for some selected categories of entrepreneurs and geographical zones;

-policy objectives are to maximize quantitative indicators (number of enterprises, jobs, sales revenue, etc.);

-forms of financial support (grants, subsidies, tax incentives);

-innovation and research and development policies for a certain category of enterprises;

-top-down policy making.
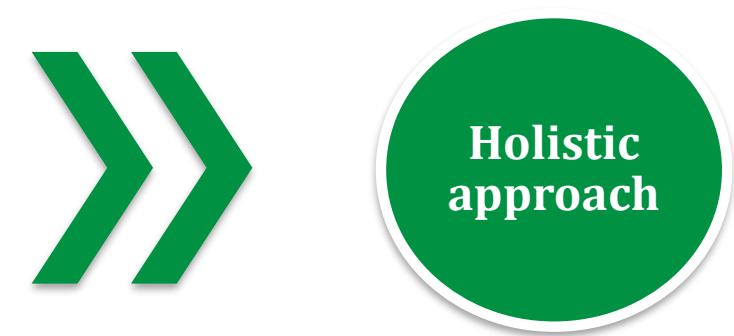

-focusing on the needs of entrepreneurs, regardless of category and geographical area;

-policy objectives lie in focusing on qualitative indicators (performance, economic impact, development potential, value added creation);

-forms of support (creation and development of networking networks, co-working spaces);

-adapting the financial support depending on the stage of development of the enterprise and diversifying the financing modalities;

-development of innovation systems in all sectors of the economy;

-policy-making by combining "topdown" and "bottom-up" principles.

Source: Developed by author.

Figure 1. Types of entrepreneurial policy approach

At the same time, it is not clear whether the successful development of business in certain regions is due to state-sponsored policies or other favorable environmental factors and what these factors are. What is certain is the need to treat the business environment in the Republic of Moldova from a new perspective, the introduction of a complex, comprehensive and integrated approach, which can be ensured by creating an entrepreneurial ecosystem that meets the real needs and problems entrepreneurs face daily. This new approach to business policy-making places little emphasis on maximizing quantitative indicators, giving priority to business quality and viability by creating a system, an environment in which businesses thrive. The objective of ecosystem policies, with a holistic approach, focuses on improving the environment in which companies operate. This is a challenging goal, since it is not clear how the authorities can intervene to create entrepreneurial ecosystems and how they can adapt the support provided to meet the diverse needs of entrepreneurs.

Presentation of the entrepreneurial ecosystem in the Republic of Moldova based on the analysis of international rankings.

The synthesis of the specialized literature offers us a vision on the approaches and elements that form an entrepreneurial ecosystem. It should be noted that there is no universal approach, or specific elements that can be applied to develop one ecosystem or another. Each region, country or locality must create its own model and address the specific problems of entrepreneurs in that geographical area.

Thus, following the analysis of the literature, we aimed to create a model of the entrepreneurial ecosystem in the Republic of Moldova, adapted to the needs of local enterprises and in accordance with the priorities of public policy documents in the entrepreneurial field (figure 2). 


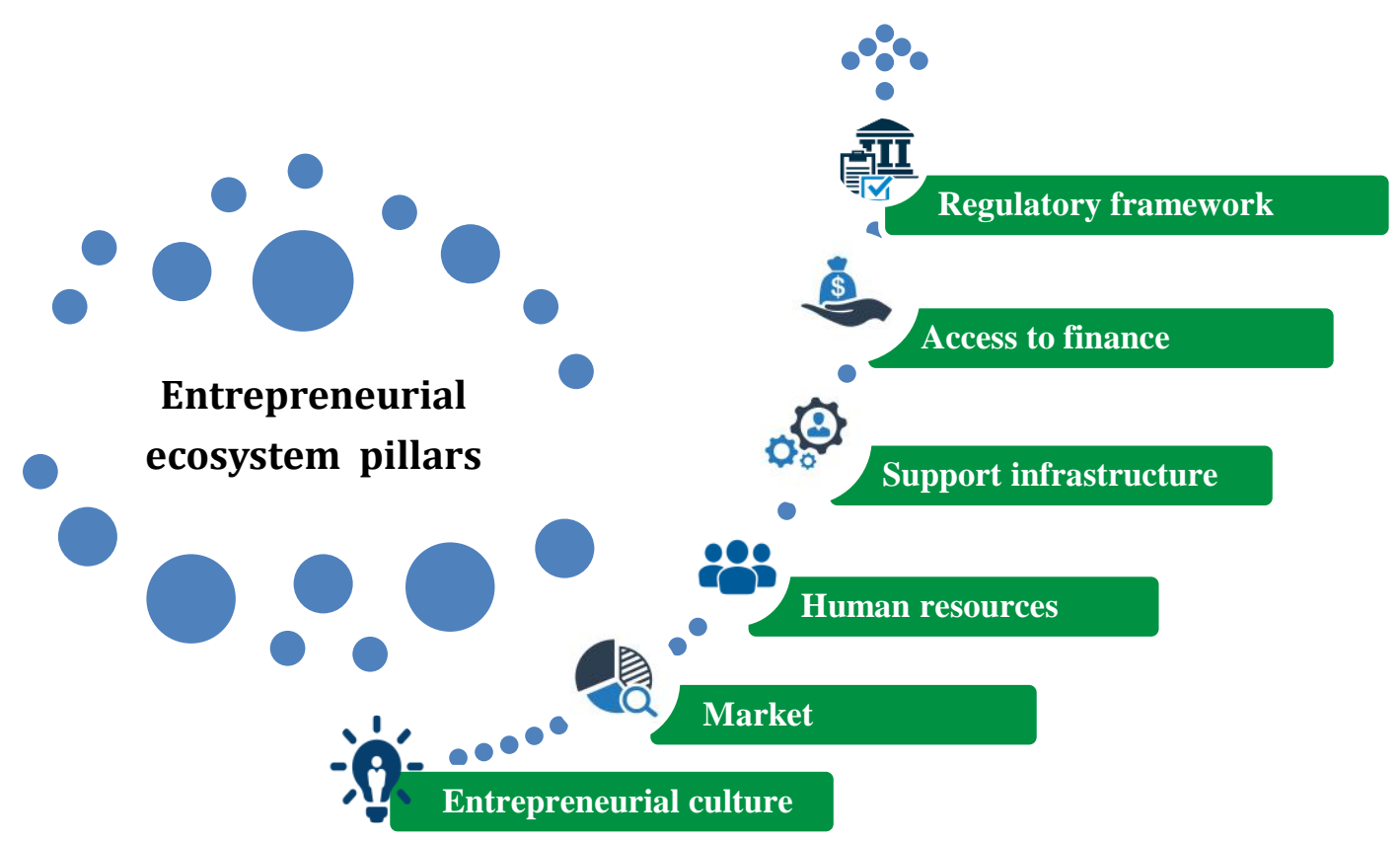

Source: Developed by author.

Six main pillars have been determined, which characterize and underlie the entrepreneurial ecosystem in the Republic of Moldova. These components are: (1) the regulatory framework; (2) access to finance; (3) support infrastructure; (4) human resources; (5) the market; (6) entrepreneurial culture. Identifying the components of the ecosystem is a first step in quantifying a vision of the directions in which measures should be taken for the efficiency and development of SMEs. The second stage of the research aims to conduct an assessment of the current ecosystem in the Republic of Moldova, using the method of analyzing the results of international rankings, conducted by organizations such as: World Bank, World Economic Forum, Babson College or Organization for Economic Cooperation and Development, etc. Following the evaluation, we will be able to determine the degree of development of the ecosystem and elaborate a set of principles, which will be the basis for the elaboration of public policies oriented towards the creation of the entrepreneurial ecosystem.

The central role in ensuring the functionality and viability of the entrepreneurial ecosystem belongs to the authorities, through the elaboration and appropriate adjustment of the regulatory framework. The state is the one that has the levers, mechanisms and tools able to majorly influence entrepreneurial activity. Despite the efforts of the authorities, international rankings show us the modest performance of entrepreneurial policies and programs. According to the "Doing Business" report, conducted annually by the World Bank, the business environment in the Republic of Moldova in 2019 has worsened compared to 2018, decreasing by 3 positions in the ranking. The most significant deterioration was recorded for the indicators: "management of building permits" and "execution of

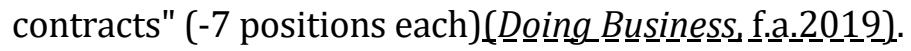

Moldova's economic freedom score is 62.0 in the "Economic Freedom Index", making its economy the 87 th freest in 2020 . Its overall score increased by 2.9 points compared to 2019 , with improved scores for government integrity and government spending. Moldova ranks 40th among the 45 countries in the European region, and its overall score is well below the regional average and approximately equal to the world average.

"The Global Innovation Index”, published by Cornell University, INSEAD (European Institute of Business Administration) and WIPO (World Intellectual Property Organization), in partnership with other organizations and institutions, provides detailed metrics on the performance of innovation in 126 countries. In 2019, compared to 2018, the Republic of Moldova registers a decrease of 10 positions in the

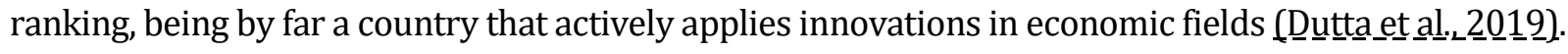


The second component, access to finance, continues to be a major impediment for entrepreneurs in the Republic of Moldova, including in surveys conducted among entrepreneurs in the country. International rankings tell us about this unfortunate aspect that creates problems in the development of the business environment. In the "Doing Business" report, the indicator on the ease of obtaining loans

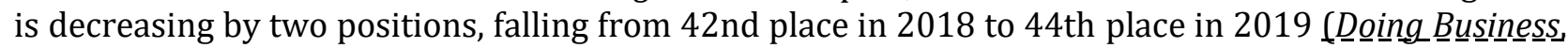
f.a.). "The Global Innovation Index" report indicates a decrease by 10 positions in 2018, 79th place, compared to 2017, 89th place, in terms of obtaining loans (Dutta_et_al...2019).

The support infrastructure in the Republic of Moldova is gaining an increasing role in the development of the entrepreneurial ecosystem. This priority is included in the Small and Medium Enterprise Sector Development Strategy for 2012-2020, creating business incubators, innovative incubators, business hubs, clusters and business support centers. Their role and mission is to inform, train, facilitate access to finance, offer spaces at preferential prices, etc. Authorities are focusing on creating support infrastructure in regions, especially in economically disadvantaged ones. The problem is that there is a risk of these infrastructure objects not achieving their purpose if there is no demand for the services they provide. The low demand is determined by various reasons: migration of the population to urban areas; immigration; low level of trust in state institutions; lack of social, economic and other perspectives; and so on. For these reasons, there is a need to address problems in an integrated way and to offer complex solutions, which aim in particular at creating favorable economic and social conditions for the population.

Staff is the only resource in a company that has the ability to increase its value over time, unlike all other resources, which wear out if not physically, then morally. (Pavalachi, 2011) As in the case personnel of an enterprise, the human capital of a country is its actual and real value. The Human Development Index, developed by the United Nations Development Program, was created to emphasize that people and their capabilities should be the key criteria for assessing a country's development, not just quantitative growth. Within this ranking, the Republic of Moldova ranks 107th out of 189 countries in 2019, aiming at achieving the key dimensions of human development: a long and healthy life, education and income level. The Republic of Moldova has improved its position in the ranking, climbing to the 107th place in 2019, compared to 2018, when it held the 112th place. (UNDP, 2020)

The social, economic and political context directly influences entrepreneurship, while social values and personal characteristics have an indirect influence but are still no less important. Culture and, specifically, social norms and positive attitudes towards entrepreneurship, have been recognized

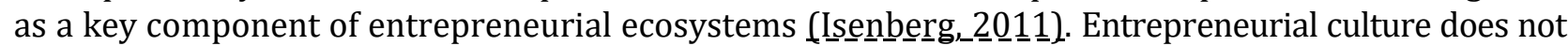
occur by chance, it is cultivated, developed and promoted by academia, authorities, international organizations and civil society. It is important to present entrepreneurial activity in a positive light, giving it the appropriate status. At the same time, we need to encourage initiatives and identify the reasons for starting a business, in order to meet the expectations of entrepreneurs.

The last pillar of the entrepreneurial ecosystem is the market. It is difficult to imagine the existence of a competitive and developed economy without a functioning sales market and without healthy connections with foreign sales markets. In this regard, too, there are shortcomings, which must be removed in order for entrepreneurs to market their services and products at competitive prices on both the local and international markets. The "Global Competitiveness" report indicates the low level of market

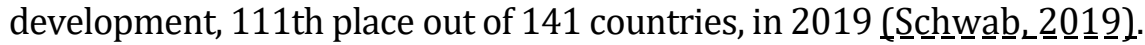

The components of the entrepreneurial ecosystem in the Republic of Moldova assessed in terms of international rankings reflect a modest development and low efficiency of public instruments/policies aimed at improving and developing small and medium enterprises. Authorities need to be aware that the development of some regions and the stagnation of others have their origins in the level of development of the ecosystem. The same support instruments, public policies and development programs applied in two different regions create a different impact.

Therefore, public policies aimed at developing a functioning entrepreneurial ecosystem must be

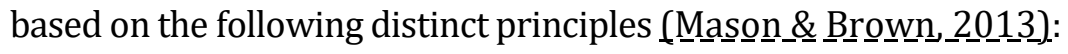

1. Each ecosystem needs a different approach, adapted to the needs of local businesses. There is no universal model of entrepreneurial ecosystems.

2. The entrepreneurial ecosystem should result from economic areas, which are already successful. 
Which means stimulating industries with proven capabilities and viability over time, that create added value, innovation and smart specialization;

3. The development of public policies aimed at the growth and development of the entrepreneurial ecosystem will ensure the combination of "bottom-up" and "top-down" principles;

4. Government initiatives need to have an integrated approach, as isolated support for specific groups of entrepreneurs tends to be ineffective in the long run. Encouraging more people to create startups is likely to have a low impact, if many of them are registered in areas with low economic growth, such as most rural areas in the Republic of Moldova. The introduction of entrepreneurship education will be ineffective if graduates move to more favorable business environments, usually migrating or roaming to urban areas. Each component of the entrepreneurial ecosystem is equally important, therefore if one of them is missing or not addressed properly, the development of the ecosystem will be negatively influenced. Consequently, the implementation of entrepreneurial policy must be holistic;

5. The approach to public policies must be constantly evolving and adapting, as entrepreneurial ecosystems are naturally complex, dynamic and must grow, develop organically, and their evolution cannot be accelerated by direct intervention. Therefore, the forms of state support will be in line with the level of maturity of the ecosystem. For example, at the emergent stage of the ecosystem, the emphasis can be on supporting business start-ups, but as the ecosystem matures, the needs of companies change, with support services needed to develop processes, train and improve human resources, support internationalization. and access to financial resources;

6. It is important to recognize the distinction between SMEs and entrepreneurial policies. SME development policies have a selective and fragmented approach, focusing on increasing the number of start-ups. Entrepreneurial policy, on the other hand, focuses on supporting businesses with high growth potential, i.e. on increasing qualitative indicators;

Practical recommendations for adjusting the entrepreneurial policy in the Republic of Moldova

The Republic of Moldova is making modest progress in developing a sustainable and inclusive entrepreneurial ecosystem. As a result, the authorities must continue their efforts to create an environment in which the number of companies can grow, but above all to focus on companies with accelerated growth potential, in order to increase their quality as well. As mentioned above, it is necessary to approach entrepreneurial policies holistically and to target those elements of the ecosystem, which reflect a marked deterioration. The analysis based on the international rankings of the national business ecosystem shows shortcomings in the following chapters, to which we propose a set of recommendations:

I. Increasing access to finance

$>$ Adoption of the draft law regulating risk capital, which has been inactive since 2015;

$>$ Increasing the access to financing of enterprises with increased potential for growth and internationalization, disregarding the field of activity;

$>$ Stimulating the use by the financing institutions of the guarantees offered by the Credit Guarantee Fund and implicitly reducing the burden for entrepreneurs on the need to pledge their own assets.

II. Promoting the development of entrepreneurial culture

$>$ Inclusion of the European Competence Framework in the field of entrepreneurship in the 2019-2020 curricular reform plans;

$>$ Promoting the examples of success and talents, as well as the positive profile of the entrepreneur in society;

$>$ Approaching the option to become an entrepreneur for students of all higher education institutions in the Republic of Moldova.

III. Development of business environment support infrastructure at national level

$>$ Currently the public organization responsible for the implementation of programs and projects in the field of entrepreneurial development is the Organization for the Development of Small and Medium Enterprises (ODIMM), based in Chisinau. We recommend opening an ODIMM branch in the north and south of the country in order to more easily and efficiently meet the needs of entrepreneurs in those areas and create entrepreneurial ecosystems in areas.

Continuing to support development: clusters, business hubs, business incubators and coworking spaces. 


\section{CONCLUSIONS}

The creation and development of the entrepreneurial ecosystem in the Republic of Moldova is not an easy task, given that the assessment of ecosystem components shows a deterioration of business conditions and the existence of various problems: limited access to finance, population emigration, small market, accentuated regional disparity, etc. The authorities, with the support of external development partners, are making continuous efforts to improve the conditions of the business environment and stimulate the creation of as many enterprises as possible throughout the country. Despite these efforts, for the most part, over $65 \%$ of businesses are created and operate in Chisinau, which shows that businesses are created and operate successfully not due to state support. Beyond support, there are other stimulating and motivating conditions that determine people to start a business, and these conditions are determined by the presence of the entrepreneurial ecosystem. The existence of functional elements of the ecosystem that stimulate and encourage companies to operate. The entrepreneurial ecosystem approach introduces a new vision, the role of the external business environment being very important and of a major influence on the business activity.

The aim of this research is to elucidate the role of entrepreneurial policies with a holistic approach to the creation of the entrepreneurial ecosystem. Public policies need to be reoriented from quantitative growth of enterprises to qualitative growth. SMEs with high growth potential are the ones that create: innovations, added value, but also competitive products / services on the national and international market. The integrated approach to entrepreneurial policies especially encourages companies with high growth potential. They do not distinguish between types of business, being supported by companies from all sectors of the economy. The support provided focuses on connecting entrepreneurs with institutions and organizations that will directly contribute to their growth and development. The approach to entrepreneurial policies must be holistic, but not focused on business categories or narrow segments of entrepreneurs. The overall aim of the policies will be to ensure a fertile environment and facilitate the connection between SMEs and other components of the entrepreneurial ecosystem, in order to facilitate innovation, access to information and financing.

\section{REFERENCES}

1. Cohen, B. (2006). Sustainable valley entrepreneurial ecosystems. Business Strategy and the Environment, 15(1), 1-14. https://doi.org/10.1002/bse.428

2. Dubini, P. (1989). The influence of motivations and environment on business start-ups: Some hints for public policies. Journal of Business Venturing, 4(1), 11-26. https://doi.org/10.1016/0883-9026(89)90031-1

3. Dutta, S., Lanvin, B., Wunsch-Vincent, S., World Intellectual Property Organization, Insead, Cornell University, and SC Johnson College of Business. (2019). Global innovation index. Creating healthy lives-The future of medical innovation 20192019.

4. Feld, B. (2012). Startup communities: Building an entrepreneurial ecosystem in your city. John Wiley and Sons, Inc.

5. Feldman, M., Francis, J., and Bercovitz, J. (2005). Creating a Cluster While Building a Firm: Entrepreneurs and the Formation of Industrial Clusters. Regional Studies, 39(1), 129-141. https://doi.org/10.1080/0034340052000320888

6. Feldman, M. P. (2014). The character of innovative places: Entrepreneurial strategy, economic development, and prosperity. Small Business Economics, 43(1), 9-20. https://doi.org/10.1007/s11187-014-9574-4

7. Harper-Anderson, E. (2018). Intersections of Partnership and Leadership in Entrepreneurial Ecosystems: Comparing Three U.S. Regions. Economic Development Quarterly, 32(2), 119-134. https://doi.org/10.1177/0891242418763727

8. Isenberg, D. (2011). Introducing the Entrepreneurship Ecosystem: Four Defining Characteristics. Forbes. $\quad$ https://www.forbes.com/sites/danisenberg/2011/05/25/introducing-theentrepreneurship-ecosystem-four-defining-characteristics/

9. Isenberg, D. J. (2010). How to Start an Entrepreneurial Revolution. Harvard Business Review, 12. 
10. Lichtenstein, G. A., and Lyons, T. S. (2001). The Entrepreneurial Development System: Transforming Business Talent and Community Economies. Economic Development Quarterly, 15(1), 3-20. https://doi.org/10.1177/089124240101500101

11. Mason, C., and Brown, D. R. (2013). ENTREPRENEURIAL ECOSYSTEMS AND GROWTH ORIENTED ENTREPRENEURSHIP. 38.

12. Roundy, P. T. (2016). Start-up Community Narratives: The Discursive Construction of Entrepreneurial Ecosystems. The Journal of Entrepreneurship, 25(2), 232-248. https://doi.org/10.1177/0971355716650373

13. Schwab, K. (2019). The Global Competitiveness Report 2019. 666.

14. Stam, E. (2015). Entrepreneurial Ecosystems and Regional Policy: A Sympathetic Critique. European Planning Studies, 23(9), 1759-1769. https://doi.org/10.1080/09654313.2015.1061484

15. Theodoraki, C., and Messeghem, K. (2017). Exploring the entrepreneurial ecosystem in the field of entrepreneurial support: A multi-level approach. International Journal of Entrepreneurship and Small Business, 31(1), 47. https://doi.org/10.1504/IJESB.2017.083847

16. World Bank Group (Ed.). (2020). Economy Profile of Central African Republic: Doing business 2020: comparing regulations in 190 economies. World Bank Group.

\section{ARTICLE HISTORY}

Received 22 June 2020

Accepted 05 November 2020 